detecting malingerers. He was gifted with marked manual dexterity, and several useful modifications of ophthalmic instruments are due to him.

With his flaxen hair and tall stature he presented a distinguished appearance. At times militant, as the writer remembers him at a meeting of the members of the honorary staffs of the London Hospitals, with Sir Rickman Godlee.in the chair, before the passing of the National Insurance Act; and as he got older, looking more benevolent, he was always worth listening to. Whether he was demonstrating his diaphragm test, or in lighter moods, when showing a pair of green glasses which had come from Delhi during the Mutiny, he commanded attention and respect.

He had a singularly alert brain, and was a good speaker with a ready sense of humour. British ophthalmology owes him a deep debt of gratitude, and much of his work will stand the test of time and not be forgotten. To his widow, herself a qualified doctor, and his four children we offer the sincere sympathy of British ophthalmology in their bereavement.

\title{
DR. GORDON NORRIE
}

News of the death of Dr. Gordon Norrie of Copenhagen on October 11, 1941, has just reached us. He was fortunate in that he died after a very short illness, and before the worst horrors of the German occupation of Denmark had begun.

Of Scottish ancestry, Dr. Norrie was born May 6, 1855, in Elsinore, the son of William Gordon Norrie and his wife, Fanny Wright. He was educated in Copenhagen, practised speaking English with - his grandfather, who had gone from Scotland to settle' as a merchant in Denmark, and entered the University of Copenhagen in 1873. He qualified as a surgeon in 1880 , and was studying ophthalmology under Professor Hansen Grut from 1879-1885. From 1885 onwards he practised in Copenhagen. He was surgeon to the Royal Institute for the Blind for 35 years, and commander of the military clinics of ophthalmology in Copenhagen from 1894-1912. He held rank in the army medical department from 1891-1918, and his last six years of service were as Commander of the Garrison Hospital in Copenhagen, with the rank of Colonel. He also served the Board of Health for a great many years, and was its vice-president for 20 years. To our columns he contributed a paper on ophthalmia neonatorum in Denmark, and in 1938 we gave a short abstract of his experiences at the Royal Institute for the Blind.

Gordon Norrie was an authority on medical history, and particularly on the history of ophthalmology. His "Den Danske Oftalmologis Historie indtil aar 1900 " appeared in 1925, and he was so kind as to send a copy to the writer of this note.

At the 450 years celebrations of the University of Copenhagen, he was created M.D. honoris causa. 
The.writer much enjoyed the friendly correspondence he had with Gordon Norrie. In it he always spoke with diffidence about his ability to write our language, but we never noticed much amiss. He was proficient in many languages, including French and German, and was a good Latin Scholar. We are happy to think that he was spared much-suffering, bodily and mental, and that he maintained his youthful outlook to the end, in spite of his great age. 'His wife died in 1940. We are indebted to his son, Captain Gordon Norrie, for the facts recorded here.

The photograph we reproduce was taken in 1929.

R.R.J.

\section{NOTES}

Combating, Trachoma has been known in Russia for

Trachoma in the Soviet Union centuries. Mention of it in literature can be found as far back as the XV century. The disease seems to have been imported by the Tartars during their invasion in the XIII century. The principal foci of trachoma were located in the region of the Middle Volga, in Transcaucasia and Central Asia.

The tsarist government took no steps to eradicate trachoma, no government measures having ever been undertaken in this direction. The only thing done was the organisation by a philanthropical society of temporary units for ophthalmological treatment. These bodies were sent to the foci of epidemics in order to estimate the incidence and the character of the disease, and to provide medical care.

The Soviet Revolution in 1917 brought with it a radical change in the social order of Russia, establishing entirely new conditions of life for the population. The control of trachoma was recognised as a matter of national concern.. Due measures were taken to record the foci of infection and to elaborate a plan and adequate methods for the control of the disease. An institute for trachoma research was founded in Kazan. Examination of the population carried out on a large scale confirmed the widespread incidence of trachoma and the large number of cases which had lost their sight because of this disease. As an infection intimately connected with the conditions of life, trachoma was not only a source of misery to those who were stricken by it, but it also inflicted heavy losses upon the state as a whole, reducing the efficiéncy of, and even completely incapacitating large numbers of people in the prime of life. The Government issued. a special decree concerning the measures of trachoma control, its general trend and character, and the scope of the work to be carried out. The decree authorised the Public Health Boards under definite conditions to impose compulsory treatment. 